\title{
Pengaruh Media Tanam terhadap Pertumbuhan Tanaman Terong (Solanum melongena L.) Dengan Sistem Hidroponik
}

\author{
Ali Al Fandi, Ruswadi Muchtar, dan Notarianto \\ Program Studi Agroteknologi Fakultas Pertanian Universitas Respati Indonesia Jakarta \\ Email: alialfandi17@gmail.com
}

\begin{abstract}
Abstrak
Tanaman terong (Solanum melongena L.) merupakan salah satu jenis sayuran yang digemari oleh masyarakat Indonesia karena memiliki banyak vitamin dan mineral yang dibutuhkan oleh tubuh. Kebutuhan akan terong terus meningkat seiring dengan bertambahnya jumlah penduduk, meningkatnya kebutuhan pangan, namun luas lahan yang cenderung menurun oleh karena itu perlu adanya upaya untuk meningkatkan hasil produksi tanaman terong. Salah satu penyebabnya adalah adanya alih fungsi lahan dari pertanian menjadi non pertanian. Karena menurunya luas lahan mengakibatkan jumlah produksi ikut menurun. Oleh karena itu, diperlukan suatu upaya meningkatkan produksi terong tersebut diarea yang memiliki lahan terbatas. Salah satu cara meningkatkan produksi dilahan terbatas adalah dengan menggunakan hidroponik yang menggunakan beberapa jenis media tanam. Tujuan penelitian ini adalah untuk mengetahui pengaruh media tanam terhadap pertumbuhan tanaman terong dengan sistem sistem hidroponik. Penelitian ini dilaksanakan di Rumah Kaca Fakultas Pertanian Universitas Respati Indonesia, pada bulan Februari sampai dengan bulan Juli 2020. Rancangan yang digunakan dalam penelitian ini adalah Rancangan Acak Lengkap (RAL) dengan satu faktor yaitu media tanam yang terdiri atas 4 perlakuan yaitu Serbuk Kayu, B Zeolit, C Arang Sekam, dan Cocopeat. Masing-masing dengan 5 ulangan. Variabel penelitian meliputi tinggi tanaman, jumlah daun, dan jumlah bunga. Hasil pengamatan pada tanaman berumur 49, 63, 77, 91, 105 dan 133 hst menunjukkan bahwa media tanam serbuk kayu menunjukkan pengaruh yang lebih baik terhadap tinggi tanaman, jumlah daun dan jumlah bunga dibandingkan dengan perlakuan media tanam lainnya. Namun, pembentukkan buah pada semua tanaman perlakuan tidak ada akibat adanya serangan penyakit Virus Mozaik Tobacco pada seluruh bagian bunga dengan intensitas sedang.
\end{abstract}

Kata Kunci : Pertanian Perkotaan, Hidroponik, Media Tanam, Tanaman Terong

\begin{abstract}
The eggplant plant (Solanum melongena L.) is one type of vegetable favored by the Indonesian people because it has many vitamins and minerals that the body needs. The need for eggplant continues to increase along with the increasing population, increasing food needs, but the land area tends to decrease, therefore it is necessary to make efforts to increase eggplant production. One of the causes is the conversion of land functions from agriculture to non-agriculture. Because the decrease in land area has resulted in decreased production. Therefore, an effort is needed to increase eggplant production in areas that have limited land. One way to increase production on limited land is to use hydroponics which uses several types of growing media. The purpose of this study was to determine the effect of planting media on the growth of eggplant plants with a hydroponic system. This research was conducted at the Greenhouse of the Faculty of Agriculture, Respati Indonesia University, from February to July 2020. The design used in this study was a completely randomized design (CRD) with one factor, namely the planting medium consisting of 4 treatments, namely Wood Powder, B Zeolite, C Husk Charcoal, and Cocopeat. Each with 5 repetitions. Research variables include plant height,
\end{abstract}

http://ejournal.urindo.ac.id/index.php/pertanian

Article History :

Sumbitted 22 Desember 2020, Accepted 30 Desember 2020, Published 31 Desember 2020 
number of leaves, and number of flowers. The results of observations on plants aged 49, 63, $77,91,105$ and 133 DAP showed that sawdust growing media showed a better effect on plant height, number of leaves and number of flowers compared to other growing media treatments. However, there was no fruit formation in all treatment plants due to the Tobacco Mosaic Virus disease attack on all parts of the flower with moderate intensity.

Keywords : Urban Agriculture, Hydroponics, Planting Media, Eggplant Plants

\section{PENDAHULUAN}

Tanaman terong (Solanum
melongena L.) termasuk salah satu
tanaman sayuran semusim yang
menghasilkan buah. Berdasarkan atas
kegunaan dan habitatnya tanaman terong
juga termasuk golongan tanaman
hortikultura yang pemanenannya dapat
dilakukan lebih dari satu kali. Secara
sistematik genetika tanaman terong
merupakan anggota Solanaceae yang
berkerabat dengan cabai, tomat, dan
kentang [1].

Tanaman terong di Indonesia umumnya diolah sebagai sayuran dalam bentuk mentah atau segar maupun bentuk olahan. Seiring dengan peningkatan atau perkembangan jumlah penduduk yang semakin tinggi dan diiringi dengan kemajuan sektor industri pariwisata dan farmasi dimungkinkan kebutuhan buah tanaman terong ini akan semakin meningkat pula. Untuk dapat memenuhi kebutuhan tersebut perlu adanya dukungan peningkatan produksi buah terong dalam budidaya tersebut. Baik secara intensifikasi, ekstensifikasi atau rehabilitasi maupun perbaikan sistem budidaya di daerah penelitian. Berdasarkan data Badan Pusat Statistik (2019), total produksi tanaman terong di DKI Jakarta per tahun dari tahun 2015 2017 adalah sebagai berikut. Pada tahun 2015 menghasilkan 15 ton, tahun 201616 ton dan tahun 201717 ton [2].

Buah terong mengandung vitamin yang baik untuk menjaga ketahanan tubuh. Setiap 100 gram bahan mentah terong mengandung 26 kalori; 1 gram protein; 0,2 gram hidrat arang; 25 IU vitamin A; 0,04 gram vitamin B; 5 gram vitamin C. Buah terong juga mempunyai khasiat sebagai obat karena mengandung alkaloid, solanin, dan solasodin [3].

Produktivitas terong nasional relatif masih rendah walaupun setiap tahun cenderung meningkat. Rendahnya produksi terong ini disebabkan oleh antara lain luas lahan budidaya terong yang kurang luas dan bentuk sistem budidaya yang belum intensif [4]. Terdapat berbagai kendala dalam peningkatkan produksi tanaman terong seperti sistem budidaya yang kurang intensif, ketersediaan lahan yang terbatas serta kurang tersediannya unsur hara yang digunakan [5]. 
Dalam budidaya tanaman sayuran di Indonesia umumnya dan DKI Jakarta khususnya kiranya sulit untuk dilakukan secara ekstensif karena akibat pesatnya perkembangan sektor industri parwisata dan sektor lainnya sehingga ketersediaan lahan yang potensial sangat terbatas. Sebagai upaya untuk meningkatkan produksi tanaman terong di daerah penelitian diantaranya adalah secara intensif dalam pengelolaannya dan perbaikan dalam sistem budidayanya. Dalam pengelolaan secara intensif ini antara lain dengan pemberian media tanam tertentu yang dapat mendukung pertumbuhan yang optimal, sedangkan perbaikan dalam sistem budidaya pada daerah DKI Jakarta khususnya didaerah perkotaan dengan menggunakan sistem hidroponik [6].

Hidroponik adalah teknik bercocok tanam dengan menekankan pada pemenuhan nutrisi, oksigen dan air bagi tanaman yang tidak menggunakan tanah sebagai media tanam. Teknologi hidroponik tidak memerlukan lahan luas namun dapat dilakukan dilahan sempit atau terbatas. Dengan adanya penggunaan media tanam selain tanah dan penambahan nutrisi bagi tanaman, tentunya perlu dicari diantara beberapa jenis bahan yang dapat digunakan sebagai media tanam yang dapat mendukung tegak dan kokohnya pertumbuhan tanaman dan ketersediaan hara yang diperlukan tanaman tersebut [7].

Media tanam adalah media atau bahan yang digunakan sebagai tempat tumbuh dan berkembangnya tanaman baik berupa tanah maupun non tanah, Media tanam merupakan komponen utama yang diperlukan dalam budidaya suatu tanaman. Ada berbagai macam media tanam, akan tetapi tidak semua jenis media tanam cocok digunakan untuk menanam suatu jenis tanaman. Media tanam yang digunakan harus disesuaikan dengan jenis tanaman yang akan ditanam. Secara umum, media tanam harus dapat menjaga kelembaban daerah sekitar akar, menyediakan cukup udara, dan dapat menahan ketersediaan unsur hara pada sistem hidroponik dan akuaponik [8]. Media tanam mempengaruhi berat kering dan berat segar tanaman yang dibudidayakan menggunakan media air [9]. Beberapa jenis media tanam yang dapat dipakai dalam sistem hidroponik seperti arang sekam, zeolit, cocopeat dan serbuk kayu, namun petani belum tahu media mana yang sesuai dengan cuaca setempat sehingga dapat menimbulkan pertumbuhan dan hasil yang optimal. Oleh karena itu untuk mengetahui pengaruh beberapa jenis media tanam terhadap 
pertumbuhan tanaman terong perlu di lakukan penelitian.

\section{METODE}

\section{Bahan dan Alat}

Bahan-bahan yang digunakan dalam penelitian ini adalah benig terong ungu varietas yuvita, rockwool, serbuk kayu, arang sekam, zeolit, cocopeat, dan larutan nutrisi hidroponik. Alat-alat yang digunakan dalam penelitian ini adalah : alat instalasi hidroponik sistem irigasi tetes (Drip Irrigation), pH meter, dan Total Disolved Solid (TDS) meter.

\section{Rancangan Penelitian}

Penelitian ini dilaksanakan dengan Rancangan Acak Lengkap (RAL) dengan 4 perlakuan dan di ulang sebanyak 5 kali. Setelah data didapatkan dilanjutkan dengan menggunakan uji Annova. Sebagai perlakuan yang diuji adalah media tanam yaitu media tanam serbuk kayu (A), Zeolit (B), Arang Sekam (C), dan cocopeat (D).

\section{Cara Kerja}

\section{Persemaian Benih}

Persemaian merupakan tahap awal dari proses budidaya tanaman baik secara hidroponik maupun konvensional. Siapkan media tanam rockwool, potong rockwool menjadi ukuran $2 \times 2 \mathrm{~cm}$. Siapkan benih terong yang akan ditanam secukupnya. Benih yang digunakan untuk hidroponik sama dengan benih yang digunakan pada saat budidaya tanaman secara konvensional. Benih disemai dengan menggunakan rockwool, sebelum disemai benih terlebih dahulu direndam diair hangat. Setelah itu, lubangi rockwool dibagian tengah dengan kedalam $2 \mathrm{~cm}$. Penyemaian dengan rockwool dilakukan dengan cara menaruh benih terong dilubang yang sudah dibuat satu lubang tanam untuk satu benih. Tambahkan sedikit air diatas rockwol tersebut. Setelah itu, rockwool disimpan ditempat yang gelap, diamkan semalam. Keesokan harinya sinari benih dengan sinar matahari langsung mulai dari pagi hingga sore hari.

\section{Pembuatan Instalasi Hidroponik}

Pembuatan instalasi hidroponik diperlukan karena sebagai tempat tumbuh benih yang sudah mulai membesar. Mulamula dengan menyiapkan alat dan bahan yang akan digunakan. Potong pipa 2 inci menggunakan gergaji menjadi beberapa bagian kecil $8 \mathrm{~cm}$ sebanyak 4 buah, $40 \mathrm{~cm}$ sebanyak 8 buah. Sambungkan pipa tersebut dengan knee atau $T$ drat untuk membelokkan air. Pada bagian tempat keluarnya air dari mesin air wp 104, diberikan selotip pipa, tujuannya adalah agar air yang keluar tidak bocor. Gunakan pipa 2 inci lainnya, lalu tandai dengan pensil setiap $40 \mathrm{~cm}$. Setelah itu dibor, lalu dipasangkan gromet 8 inci pada lubang hasil bor tersebut. Setelah gromet 
terpasang sambungkan dengan selan pe 7 inci. Gunakan selotip pipa agar mengantisipasi kebocoran. Pasangkan kran air di bagian ujung selang pe, lalu diatur agar air yang akan keluar nantinya tidak terlalu deras.

Setelah sistem hidroponik sudah selesai. Taruh polybag yang sudah diisi media tanam dibawah selang pe 7 inci tersebut. Hidroponik sistem tetes sudah siap untuk digunakan.

\section{Persiapan Polybag}

Penelitian ini dilakukan dengan hidroponik sistem tetes yang ditanami tanaman terong. Polybag yang digunakan ukuran $20 \mathrm{~cm} \times 40 \mathrm{~cm}$. Masing-masing polybag yang digunakan ditanami satu buah tanaman terong. Setiap polybag yang digunakan diisi satu media tanam tanpa pemberian larutan nutrisi kedalamnya. Pada penelitian ini media tanam yang digunakan meliputi serbuk kayu, arang sekam, zeolit dan cocopeat.

\section{Pindah Tanam}

Pindah tanam dilakukan setelah 2 minggu setelah tanam atau setelah bibit tanaman terong sudah memunculkan 3-4 helai daun. Setelah bibit tanaman terong siap tanam, pindahkan bibit tanaman terong ke hidroponik sistem tetes. Bibit tanaman terong dipindahkan bersama dengan media semainya ke polybag pada hidroponik sistem tetes.

\section{Aplikasi Larutan Nutrisi Hidroponik}

Pengaplikasian larutan nutrisi hidroponik dilakukan setelah bibit tanaman terong selesai pindah tanam disistem hidroponik sistem tetes. Larutan nutrisi langsung dipakai pada saat hari pertama pindah tanam hingga selesai masa penelitian. Larutan nutrisi diganti setiap seminggu sekali, hal ini agar setiap minggunya tanaman memperoleh larutan nutrisi yang baru. Untuk mengukur kepekatan larutan nutrisi bisa di ukur dengan menggunakan EC Meter atau TDS atau PH meter.

\section{Pemeliharaan}

Pemeliharan dalam hal ini dilakukan, apabila ada saluran air yang keluar dari pipa pe $7 \mathrm{~mm}$ yang terhambat, maka bisa langsung dibersihkan agar sistem pengairannya kembali normal. Penggantian air dilakukan setiap 5 hari sekali, untuk menghindari hadirnya lumut. Ketika melakukan penggantian air, mesin air wp 104 juga ikut dibersihkan untuk menghindari adanya penyebab aliran air terhambat. Pemangkasan dilakukan apabila ada tunas air yang muncul, daun yang ternaungi atau terlalu rimbun, serta daun yang sakit. Pemasangan ajir dilakukan agar tanaman terong tidak mudah roboh atau mencegah tanaman tumbuh tidak rebah ke arah samping kanan, atau samping kiri. 


\section{Variabel Pengamatan}

Tinggi tanaman diukur per polybag pada saat tanaman terong berumur 49 HST dan 63 HST. Tanam terong ungu diukur mulai dari pangkal batang yang telah diberi tanda sebelumnya, sampai titik tertinggi dari batang utama tanaman. Jumlah helaian daun diketahui dengan cara menghitung jumlah daun dari pangkal batang bagian bawah hingga bagian atas. Pengamatan jumlah daun dilakukan pada saat tanaman terong berumur 49 HST dan 63 HST. Jumlah bunga pertanaman dihitung dan dijumlahkan pada saat tanaman mulai memunculkan bunga sampai akhirnya bunga itu menjadi berbuah. Pengamatan dilakukan dua minggu sekali disaat tanaman terong mulai berbunga.

\section{Analisis Data}

Data hasil pengamatan yang dianalisis dengan menggunakan analisis ragam berdasarkan uji taraf $5 \%$. Apabila terdapat beda nyata pada perlakuan yang digunakan maka dilanjutkan dengan $\mathrm{Uji}$ Beda Nyata Terkecil (Uji BNT).

\section{HASIL DAN PEMBAHASAN}

Pengaruh Media Tanam Terhadap Tinggi Tanaman Terong Solanum melongena $L$

Pengaruh media tanam terhadap tinggi tanaman terong Solanum melongena $L$ dilakukan pada saat tanaman terong berumur 49 hst, 63 hst, 77 hst, 91 hst, 105 hst, 119 hst dan umur 133 hst disajikan pada Tabel 1. Media tanam serbuk kayu (A) memberikan pengaruh paling baik terhadap tinggi tanaman terong diikuti media tanam arang sekam, zeolit dan cocopeat. Media tanam serbuk kayu mengandung selulosa dan zat lain yang cukup dapat merangsang atau mendorong pembentukan dan perbanyakan cell-cell meristimatik pada ujung batang. Sehingga dapat mempercepat proses pemanjangan cell atau penambahan tinggi tanaman terong. Serbuk kayu mengandung selulosa $47,5 \%$, lignin $29,9 \%$. Lignin adalah suatu campuran zat-zat organik yang terdiri dari zat karbon $(\mathrm{C})$, zat air $\left(\mathrm{H}_{2}\right)$ dan oksigen $\left(\mathrm{O}_{2}\right)$. Selulosa merupakan komponen struktur dinding cell pada tumbuhan [10].

Tabel 1. Pengaruh Media Tanam Terhadap Tinggi Tanaman Terong Solanum melongena $L$

\begin{tabular}{cccccccc}
\hline & \multicolumn{7}{c}{ Tinggi Tanaman (cm) } \\
\cline { 2 - 8 } Perlakuan & Umur & Umur & Umur & Umur & Umur & Umur & Umur \\
& 49 & 63 & 77 & 91 & 105 & 119 & 133 \\
& HST & HST & HST & HST & HST & HST & HST \\
\hline A & $18,0 \mathrm{~cd}$ & $29,8 \mathrm{~d}$ & $42,6 \mathrm{~d}$ & $62,4 \mathrm{~d}$ & $68,2 \mathrm{~cd}$ & $70,8 \mathrm{c}$ & $73,2 \mathrm{c}$ \\
B & $16,4 \mathrm{bc}$ & $22,8 \mathrm{ab}$ & $28,4 \mathrm{a}$ & $45,4 \mathrm{~b}$ & $48,6 \mathrm{ab}$ & $50,8 \mathrm{ab}$ & $51,6 \mathrm{ab}$ \\
$\mathrm{C}$ & $15,2 \mathrm{ab}$ & $21,8 \mathrm{a}$ & $38,4 \mathrm{bc}$ & $51,8 \mathrm{bc}$ & $63,6 \mathrm{c}$ & $71,6 \mathrm{~cd}$ & $81,4 \mathrm{~d}$ \\
\hline
\end{tabular}




\begin{tabular}{llllllll}
\hline D & $14,0 a$ & $23,4 a b c$ & $32,0 a b$ & $34,0 a$ & $37,4 a$ & $47,2 a$ & $47,4 a$ \\
\hline
\end{tabular}

Keterangan : $A=$ serbuk kayu, B = Zeolit, $C=$ Arang Sekam, dan D = cocopeat. Angka-angka yang diikuti oleh huruf yang sama pada kolom yang sama berarti tidak berbeda menurut Uji BNT $5 \%$

Media tanam arang sekam (C) memberikan pengaruh baik kepada tinggi tanaman terong tetapi masih lebih rendah dibandingkan dengan media tanam serbuk kayu (A). Hal ini terjadi karena beberapa jenis hara yang tertahan pada media tanam arang sekam kurang dapat menahan unsur hara yang diperlukan untuk perkembangan cell meristimatik pada ujung batang. Arang sekam adalah sekam bakar yang berwarna hitam, yang dihasilkan dari pembakaran yang tidak sempurna, yang telah banyak digunakan sebagai media tanam secara komersial pada sistem hidroponik. Komposisi arang sekam paling banyak ditempati oleh Silika, yaitu $52 \%$ dan C sebanyak 31\%. Komponen lainnya adalah $\mathrm{Fe}, \mathrm{K}, \mathrm{Mg}, \mathrm{Ca}, \mathrm{Mn}$ dan $\mathrm{Cu}$ dalam jumlah relatif kecil. Karakteristik arang sekam adalah sangat ringan dan kasar, kapasitas menahan air yang tinggi, warnanya yang hitam, serta dapat menahan pertumbuhan gulma [11].

$$
\text { Media tanam zeolit dapat }
$$
berpangaruhi nayata terhadap tinggi tanaman terong namun masih lebih rendah dibandingkan dengan media tanam arang sekam (B) dan tidak beda nyata dengan perlakuan cocopeat (D). Hal ini terjadi karena zeolit kurang dapat menahan zat hara untuk perkembangan sel-sel meristimatik. Zeolit memiliki banyak kegunaan dalam berbagai aspek karena sebagai penyerap, penukar ion, dan sebagai katalisator yang bersifat lunak dan kering [12].

$$
\text { Media tanam cocopeat juga }
$$
menghasilkan tinggi tanaman tanaman terong yang rendah. Hal ini menunjukkan bahwa media tanam cocopeat kurang dapat menahan hara yang dapat merangsang pembelahan sel-sel meristimatik pada ujung tanaman yang dapat menambah tinggi tanaman terong. Perkembangan sel-sel meristematik pada bagian batang dapat memacu tinggi tanaman [13].

Menurut hasil pengamatan bahwa terjadinya pertumbuhan tanaman terong pada semua media tanam yang digunakan disebabkan air yang diserap oleh akar tanaman mengandung unsur hara yang sudah terlarut didalamnya kemudian diangkut kebagian tanaman, seperti bagian daun, melalui jaringan xilem. Oleh karena. penelitian ini menggunakan sistem hidroponik, maka tanaman memerlukan unsur hara tambahan selain dari unsur hara yang terkandung pada masing-masing media tanam. Penambahan unsur hara 
tersebut dilakukan dengan cara menambahkan larutan nutrisi hidroponik kepada tanaman terong. Supaya air dapat diserap oleh akar tanaman, maka air harus di ionisasikan. Proses masuknya air kedalam akar-akar adventif tanaman terong dapat dilalui dengan beberapa cara seperti adanya proses difusi, proses osmosis, proses kohesi, proses adhesi, proses imbibisi dan proses emulsi. Proses difusi dapat terjadi jika tekanan dari luar cell lebih besar bila dibandingkan dengan tekanan dalam cell tersebut. Proses osmosis adalah perpindahan molekul zat cair dari yang berkosentrasi tinggi ke wilayah yang konsentrasinya rendah. Proses osmosis ini dapat terjadi ketika molekul air dari larutan hipotonik (konsentrasi rendah) berpindah ke larutan hipertonik (konsentrasi tinggi). Proses kohesi adalah gaya tarik menarik antara molekul air atau ion yang sejenis. Proses adhesi adalah gaya tarik menarik antara molekul atau ion yang tidak sejenis. Proses imbibisi adalah proses masuknya air kedalam cell melalui pori - pori cell atau porus. Jika air yang masuk kedalam porus ini hanya melewati satu porus maka dinamakan imbiban, tetapi jika air yang masuk kedalam cell melewati banya porus maka dinamakan imbibisi. Proses emulsi dapat terjadi pada dinding cell, karena pada dinding cell terdapat lapisan Protein
Lipid Protein (PLP). Pada bagian PLP ini air tidak dapat lewat, karena lapisan Lipid atau lemak, menahan laju air. Sehingga lemak harus diemulsikan terlebih dahulu oleh air, agar air dapat melewati lapisan PLP.

Pada saat pertumbuhan vegetatif, tanaman terong sangat memerlukan unsur hara makro yang cukup terutama nitrogen $(\mathrm{N})$.

Nitrogen (N) berperan sebagai pemacu pertumbuhan batang, daun, dan akar tanaman, penyusun hormon, penyusun enzim dan penyusun vitamin. Semakin meningkat pertumbuhan vegetatif tanaman terong, maka kebutuhan unsur hara nitrogen $(\mathrm{N})$ juga meningkat [14].

Jenis hidroponik yang digunakan adalah hidroponik sistem tetes. Hidroponik sistem tetes ini bekerja dengan cara meneteskan nutrisi ke media tanam sehingga nutrisi tersebut dapat diserap oleh akar tanaman. Media tanam yang baik merupakan media yang dapat mendukung pertumbuhan tanaman, serta dapat mengikat atau menyimpan unsur hara bagi tanaman tersebut. Penunjang keberhasilan dari sistem budidaya hidroponik sistem tetes ini adalah media tanam yang bersifat tahan terhadap air dan aerasi baik serta nutrisi yang tercukupi untuk pertumbuhan tanaman.

Karena menggunakan hidroponik maka diperlukan penambahan nutrisi yang harus mengandung unsur hara makro dan 
mikro. Larutan nutrisi hidroponik terkandung makro yaitu nitrogen (N), phospat (P), kalium (K), calcium (Ca), magnesium (Mg) dan sufur (S) sedangkan unsur mikro terdiri atas besi (Fe), chlorine $(\mathrm{Cl})$, mangan (Mn), kuprum (Cu), seng ( $\mathrm{Zn})$, boron (B), dan molybdenum (Mo) [7].

Pengaruh Media Tanam Terhadap Jumlah

Daun Tanaman Terong Solanum melongena $L$
Pengamatan pengaruh media tanam terhadap jumlah daun tanaman terong dilakukan pada saat tanaman terong berumur 49 hst, 63 hst, 77 hst, 91 hst, 105 hst, 109 hst dan umur 133 hst. Pengaruh media tanam terhadap jumlah daun tanaman terong Solanum melongena L disajikan seperti tertera pada Tabel 2.

Tabel 2. Pengaruh Media Tanam Terhadap Jumlah Daun Tanaman Terong Solanum melongena $L$

\begin{tabular}{cccccccc}
\hline & \multicolumn{7}{c}{ Jumlah Daun (helai) } \\
\cline { 2 - 7 } Perlakuan & Umur & Umur & Umur & Umur & Umur & Umur & Umur \\
& 49 & 63 & 77 & 91 & 105 & 119 & 133 \\
& HST & HST & HST & HST & HST & HST & HST \\
\hline A & $6,6 \mathrm{~cd}$ & $7,2 \mathrm{bc}$ & $10,0 \mathrm{~d}$ & $11,8 \mathrm{~d}$ & $14,0 \mathrm{~d}$ & $14,6 \mathrm{bcd}$ & $12,8 \mathrm{bc}$ \\
B & $5,8 \mathrm{~b}$ & $6,8 \mathrm{~b}$ & $5,4 \mathrm{ab}$ & $9,4 \mathrm{bc}$ & $10,0 \mathrm{ab}$ & $13,4 \mathrm{~b}$ & $9,6 \mathrm{a}$ \\
C & $6,0 \mathrm{bc}$ & $7,2 \mathrm{bc}$ & $6,8 \mathrm{bc}$ & $9,2 \mathrm{~b}$ & $11,8 \mathrm{bc}$ & $13,8 \mathrm{bc}$ & $14,4 \mathrm{bcd}$ \\
D & $5,0 \mathrm{a}$ & $5,2 \mathrm{a}$ & $4,6 \mathrm{a}$ & $6,2 \mathrm{a}$ & $8,0 \mathrm{a}$ & $7,2 \mathrm{a}$ & $11,8 \mathrm{ab}$ \\
\hline
\end{tabular}

Keterangan : $\mathrm{A}=$ serbuk kayu, $\mathrm{B}=$ Zeolit, $\mathrm{C}=$ Arang Sekam, dan $\mathrm{D}=$ cocopeat. Angka-angka yang diikuti oleh huruf yang sama pada kolom yang sama berarti tidak berbeda menurut Uji BNT $5 \%$

Pada Tabel 2 dapat diketahui bahwa semua media tanam yang digunakan tampak berpengaruh terhadap jumlah daun tanaman terong. Namun demikian perlakuan media tanam cocopeat (D) memberikan pengaruh jumlah daun paling rendah dan sedikit. Hingga akhir pengamatan, media tanam serbuk kayu menunjukkan pengaruh beda nyata lebih baik dibandingkan perlakuan lain. Jumlah daun berkaitan dengan tinggi tanaman dimana semakin tinggi tanaman maka semakin banyak daun yang terbentuk. Semakin banyak jumlah daun pada suatu tanaman maka semakin banyak pula cahaya yang terserap oleh tanaman untuk proses fotosintesis, sehingga sangat berpengaruh dalam pertumbuhan dan perkembangan tanaman [13]. Daun tanaman terong merupakan hasil pertumbuhan vegetatif yang berlangsung proses fotosintesis. Adanya zat hijau daun (klorofil) di dalam internal kloroplas yang terdapat di jaringan mesofil menyebabkan 
daun berwarna hijau. Pada bagian internal kloroplas terdapat pigmen fotosintesis yang disebut thilakoloid yang berbentuk pipih. Pada posisi tertentu thilakoloid akan menumpuk rapi membentuk struktur yang disebut granum. Thilakoloid yang memanjang menghubungkan granum yang satu dengan yang lain dinamakan stroma. Fungsi dari kloroplas ini adalah sebagai tempat berlangsungnya fotosintesis [15].

Pemberian pupuk yang sedikit, tidak akan berpengaruh banyak terhadap produksi tanaman [16]. Oleh karena itu perlu untuk diketahui juga bahwasanya kandungan nutrisi yang tepat dapat meningkatkan produksi tanaman. Nutrisi

Tabel 3. Pengaruh Media Tanam Terhadap Jumlah Bunga Tanaman Terong Solanum melongena $L$

\begin{tabular}{ccccc}
\hline \multirow{3}{*}{ Perlakuan } & \multicolumn{4}{c}{ Jumlah Bunga } \\
\cline { 2 - 5 } & $\begin{array}{c}\text { Umur 91 } \\
\text { HST }\end{array}$ & $\begin{array}{c}\text { Umur 105 } \\
\text { HST }\end{array}$ & $\begin{array}{c}\text { Umur 119 } \\
\text { HST }\end{array}$ & $\begin{array}{c}\text { Umur 133 } \\
\text { HST }\end{array}$ \\
\hline A & $0 \mathrm{a}$ & $0,4 \mathrm{a}$ & $1,4 \mathrm{c}$ & $0,8 \mathrm{bc}$ \\
B & $0,8 \mathrm{c}$ & $0,8 \mathrm{~b}$ & $0,6 \mathrm{a}$ & $0,2 \mathrm{a}$ \\
C & $1,4 \mathrm{~b}$ & $0,4 \mathrm{a}$ & $0,8 \mathrm{~b}$ & $0,6 \mathrm{~b}$ \\
D & $0 \mathrm{a}$ & $0,8 \mathrm{~b}$ & $0,8 \mathrm{~b}$ & $0,6 \mathrm{~b}$ \\
\hline
\end{tabular}

Keterangan : $\mathrm{A}=$ serbuk kayu, $\mathrm{B}=$ Zeolit, $\mathrm{C}=$ Arang Sekam, dan $\mathrm{D}=$ cocopeat. Angka-angka yang diikuti oleh huruf yang sama pada kolom yang sama berarti tidak berbeda menurut Uji BNT $5 \%$

Tabel 3. menunjukkan bahwa pada umur 91 hst jumlah bunga terong yang dihasilkan rendah atau sedikit tetapi pada umur 119 hst jumlah bunga terong yang dihasilkan tinggi dan beda nyata dengan yang lain. Media tanam yang memberikan pengaruh terbaik adalah serbuk kayu. Hal ini karena dari hasil Uji BNT $5 \%$ yang sesuai dengan kebutuhan tanaman dapat meningkatkan jumlah daun, selain itu pula dapat menambah luas daun tanaman [15].

Pengaruh Media Tanam Terhadap Jumlah Bunga Tanaman Terong Solanum melongena $L$

Pengamatan pengaruh media tanam terhadap jumlah bunga tanaman terong dilakukan pada saat tanaman terong berumur 91 hst, 105 hst, 119 hst dan umur 133 hst. Pengaruh media tanam terhadap jumlah bunga tanaman terong disajikan pada Tabel 3. 
sama yaitu 0,8 , dan media tanam serbuk kayu memberikan pengaruhnya kepada jumlah bunga tanaman terong yaitu 1,4.

Berdasarkan pengamatan pada umur 91 hst media tanam serbuk kayu dan cocopeat tidak menghasilkan pengaruh terhadap jumlah bunga karena pada media tanam serbuk kayu dan cocopeat pertumbuhan tanamannya lebih mengarah pada tinggi tanaman dan jumlah daun. Dalam proses pertumbuhan awal, semua unsur hara digunakan untuk pertumbuhan vegetatif sedangkan proses generatif seperti pada pembungaan kurang mendapat unsur hara tanaman [13].

Bunga pada tanaman terong merupakan hasil pertumbuhan generatif yang berfungsi sebagai alat perkembangbiakan secara generatif. Pada bunga inilah terjadi proses pembuahan sel kelamin betina (putik) oleh sel kelamin jantan (serbuk sari). Pada saat tanaman terong mulai mengeluarkan bunga, maka unsur hara untuk mendukung pembungaan sangat dibutuhkan terutama unsur hara phospat (P).

Unsur hara phospat berfungsi untuk memacu tanaman terong masuk ke dalam fase pertumbuhan generatif atau menumbuhkan bunga, dan memperbesar presentase pembentukan bunga. Fosfat merupakan sumber energi bagi tanaman yang berperan dalam proses pertumbuhan bunga, buah dan biji sehingga sangat dibutuhkan pada fase perumbuhan generatif [17]. Fosfat merupakan bagian dari pembentukan DNA dan RNA pada saat pembentukan buah dan biji buah [14].

Pada saat pertumbuhan vegetatif tanaman terong berlangsung dengan baik, namun dalam pertumbuhan secara generatif tanaman terong belum bisa berbuah hanya sampai berbunga saja karena kekurangan unsur hara Phospat (P). Hal ini karena semakin tinggi tanaman, membuat unsur hara ini dibutuhkan lebih banyak lagi. Rendahnya hasil terong dapat disebabkan oleh berbagai faktor antara lain, media tanam yang kurang subur, cara budidaya yang kurang baik, dan kondisi cuaca setempat yang kurang mendukung [18].

Tanaman terong memerlukan kebutuhan unsur hara berkisar 1.750 $2.450 \mathrm{ppm}$ [7]. Dan tanaman terong membutuhkan $\mathrm{pH}$ air yang ideal berkisar pH 6. Pada penelitian ini digunakan nutrisi dengan 1.750 ppm, karena untuk mengetahui apakah tanaman terong dapat tumbuh dan berkembang dengan kondisi tersebut. Pada lampiran 7 menunjukkan bahwa nutrisi yang didapatkan pada masing - masing perlakuan termasuk masih kurang dan $\mathrm{pH}$ air yang ditunjukkan oleh alat pengukur $\mathrm{pH}$ air menunjukkan angka dibawah $\mathrm{pH} 6$. Sehingga membuat 
tanaman terong mengalami kekurangan unsur hara atau difesiensi unsur hara dan tanaman terong yang digunakan belum dapar menghasilkan buah terong.

Selama penelitian berlangsung, tanaman terong yang digunakan belum dapat menghasilkan buah. Hal ini disebabkan karena, pemberian nutrisi bagi tanaman terong yang masih kurang, $\mathrm{pH}$ air yang digunakan belum sesuai, adanya gangguan dari penyakit Virus Mozaik Tobacco (TMV). yang ada pada tanaman terong, dan suhu udara yang tinggi menyebabkan kerja enzim dan hormon terhambat. Dalam proses pertumbuhan dan pembentukan buah diperlukan adanya unsur hara yang cukup tersedia. Dan terjadinya persarian atau pertemuan antara putik dan serbuk sari didalam bunga untuk menjadi bakal buah [13].
Intensitas Serangan Hama Kutu Putih Bemisia tabaci

Selama penelitian berjalan tanaman terong mendapat gangguan dari hama kutu putih Bemisia tabaci. Intensitas serangan hama dihitung menggunakan rumus [19]. Hama Bemisia tabaci mulai mengganggu tanaman terong semenjak umur tanaman 49 hst. Hama ini mengganggu tanaman terong pada perlakuan A2, A3, B1, B2, D3 dan D4. Hama ini ditemukan pada bagian bawah daun. Kerusakan yang disebabkan oleh kehadiran hama ini sebesar $40 \%$ atau termasuk kategori serangan "sedang", seperti pada Gambar 1. Gejala yang ditimbulkan pada tanaman terong akibat kehadiran hama ini adalah daun muda menguning dan mengkriting dan jika dibiarkan begitu saja akan mengakibatkan daun tersebut layu dan mati.
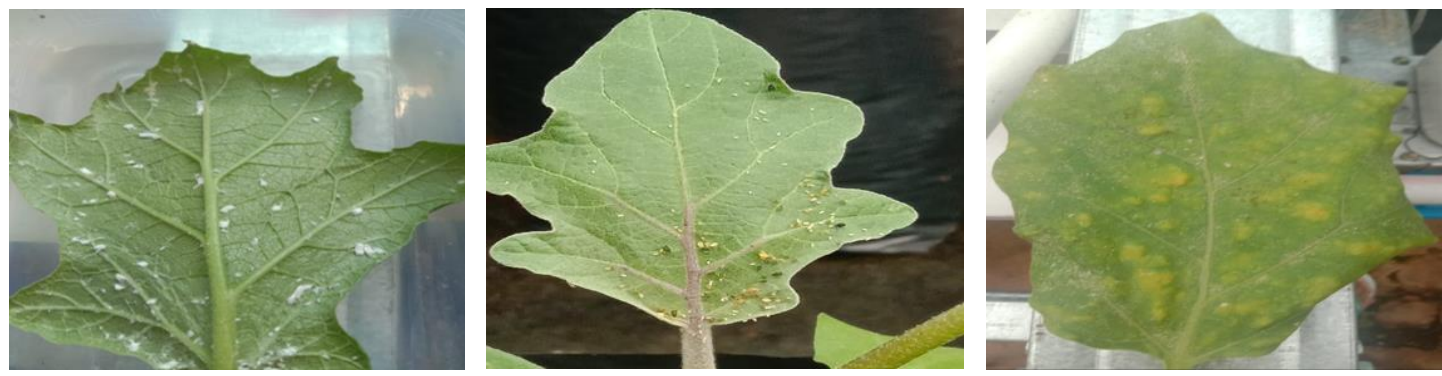

Gambar 1. Daun tanaman terong terserang hama dan penyakit(A = Kutu Putih Bemisia Tabaci, $\mathrm{B}=$ Myzus persicae, dan C = Virus Mozaik Tobacco (TMV)

Intensitas Serangan Hama Kutu Daun Myzus persicae

Hama kutu daun Myzus persicae mulai mengganggu tanaman terong semenjak umur tanaman 49 hst. Hama ini ditemukan pada bagian atas daun maupun bagian bawah daun. Dampak kehadiran hama dihitung menggunakan rumus [19]. 
Hama Myzus persicae menyerang tanaman terong pada perlakuan (B1, B2, B3, A3, A4 dan A5). Tingkat kerusakan akibat kehadiran hama ini sebesar $40 \%$ atau termasuk kategori serangan "sedang", seperti pada Gambar 1. Gejala yang ditimbulkan pada tanaman terong akibat kehadiran hama ini adalah daun mengkriting dan akan berwarna kuning.

Intensitas Penularan Penyakit Virus Mozaik Tobacco (TMV)

Dari hasil pengamatan tampak adanya serangan penyakit Virus Mozaik Tobacco (TMV). Penyakit ini menyerang tanaman terong semenjak umur tanaman 90 hst. Penyakit Mozaik Tobaco (TMV) menyerang tanaman terong pada perlakuan (A2, A3, B1, B2, D3 dan D4). Penyakit ini ditularkan oleh hama kutu putih Bemisia tabacci. Tingkat serangan yang disebabkan oleh penyakit ini sebesar $40 \%$ atau termasuk kategori serangan "sedang", seperti pada Gambar 1. Serangan penyakit ini banyak terjadi pada daun muda dan ujung bunga. Pada bagian daun dan bunga akan terlihat seperti embun tepung. Hal ini sesuai dengan pendapat Hasyim et al. (2016) yang menyatakan bahwa embun tepung pada daun tanaman akan mengurangi efisiensi fotosintesis tanaman. Sedangkan pada bagian bunga dapat menghambat proses penyerbukan dan pembuahan [20].

\section{SIMPULAN}

Media tanam serbuk kayu menunjukkan pengaruh lebih baik dan beda nyata dibandingkan perlakuan lain terhadap tinggi tanaman, jumlah daun, dan jumlah bunga tanaman terong. Kemudian diikuti oleh media tanam secara berurutan yaitu, arang sekam, zeolit dan cocopeat. Serangan penyakit Virus Mozaik Tobacco (TMV) dengan intensitas sedang pada bunga dapat mengakibatkan kegagalan proses pembuahan tanaman terong.

\section{DAFTAR PUSTAKA}

Rukmana, R. 1994. Bertanam Terung. Kanisisus. Yogyakarta.

Badan Pusat Statistik. 2019. Produksi Tanaman Terong di DKI Jakarta. Jakarta.

Sunarjono. H. 2013. Bertanam 30 Jenis Sayuran. Penebar Swadaya. Jakarta.

Simatupang. 2014. Sayuran Jepang.

Penebar Swadaya. Jakarta.

Suryani, R. 2015. Hidroponik Budidaya Tanaman Tanpa Tanah. ARCITRA. Yogyakarta. 191p.

Nugraha, R.U. 2015. Sumber Sebagai Hara Pengganti $A B$ Mix pada budidaya Sayuran daun secara hidroponik. J. Hort. Indonesia 6(1): 11-19.

Isnan,M. 2019. Tanya Jawab Hidroponik. Penebar Swadaya. Jakarta. 
Ramadhan, M. I., Suryani, dan R. Nurjasmi. 2016. Pengaruh Ikan Nila dan Media Tanam terhadap Pertumbuhan Tanaman Selada (Lactuca sativa L.) Sistem Akuaponik. Jurnal IImiah Respati. 8(1): 559-567.

Suryani dan R. Nurjasmi. 2016. Pengaruh Jenis Ikan dan Media Tanam terhadap Pertumbuhan dan Hasil Tanaman Sayuran Buah pada Sistem Akuaponik. Jurnal IImiah Respati. 2(9): 626-635.

Fengel, D., dan Wengener, G. 1995, Kandungan Kayu Jati. Diterjemahkan Oleh Handjono Sastrohamidjojo. Gadjah Mada University Press. Yogyakarta.

Istiqomah, S. 2014. Menanam Hidroponik. Azka Press. Jakarta.

Aidha, N. N. 2013. "Aktivasi Zeolit secara Fisika dan Kimia untuk Menurunkan Kadar Kesadahan (Ca dan Mg) dalam Air Tanah". J. Kimia Kemasan, 31(1), $58-64$.

Haryadi,S.S. 1996. Pengantar Agronomi.

Departemen Agronomi Fakultas Pertanian. Intitut Hanafiah, K.A. 2018. Dasar - Dasar IImu Tanah. Pt. Raja Grafindo Persada. Depok. Pertanian Bogor. Gramedia Pustaka Utama. Jakarta.

Lakitan, B. 2007. Dasar-dasar Fisiologi Tumbuhan. PT. Raja Grafindo Persada. Jakarta.
Parnata, A. S. 2010. Meningkatkan Hasil Panen dengan Pupuk Organik. Agomedia Pustaka. Jakarta.

Hendra, H. Agus dan A. Andoko. 2014. Bertanam Sayuran Hidroponik Ala Paktani Hydrofarm, PT. Agromedia Pustaka. Jakarta.

Duaja, M. D., Arzita, S. P. 2013. Analisis Tumbuh Dua Varietas Terung (Solanum melongena L.) pada Perbedaan Jenis pupuk Organik Cair. Bioplantae. 2(1): 33-39.

Herwidyarti, K. H., Ratih, S., dan Sembodo, D. R. J. 2013. Keparahan penyakit antraknosa pada Cabai (Capsicum annum L.) dan Berbagai Jenis Gulma. Jurnal Agrotek Tropika, 1(1): 102-106. Hasyim, A., Setiawati W., dan Liferdi L. 2016. "Kutu Kebul Bemisia Tabaci Gennadius (Hemiptera: Aleyrodidae) Penyebar Penyakit Virus Mosaik Kuning pada Tanaman Terung. IPTEK Hortikultura. 12: 50-54. 